\title{
Follow-up consultations on growth and development: the meaning for quilombo mothers
}

\author{
Consulta de acompanhamento do crescimento e desenvolvimento: significados de mães quilombolas \\ Consulta de acompañamiento del crecimiento y desarrollo: significados de madres quilombolas
}

\author{
Elenilda Farias de Oliveira ${ }^{1}$ \\ Climene Laura de Camargo ${ }^{1}$ \\ Nadirlene Pereira Gomes ${ }^{1}$ \\ Luana Moura Campos ${ }^{1}$ \\ Viviane Silva de Jesus ${ }^{1}$ \\ Maria Carolina Ortiz Whitaker ${ }^{1}$
}

1. Universidade Federal da Bahia.

Salvador, BA, Brazil.
Corresponding author:

Elenilda Farias de Oliveira.

E-mail: didafarias@yahoo.com.br

Submitted on $08 / 08 / 2017$

Accepted on 10/20/2017.

DOI: 10.1590/2177-9465-EAN-2017-0054

\section{Abstract}

Objective: To know the meanings of follow-up consultations on growth and development from the perspective of mothers living in quilombos. Method: A qualitative research was carried out with 26 mothers of under one-year-old children who attended the Family Health Unit of Ilha de Maré, Bahia, Brazil. The data of the interviews were systematized using analysis of thematic content based on symbolic interactionism. Results: Four categories were identified that reflect the symbolism of quilombola mothers about child consultations: growth assessment, examination of the general health conditions, guidance on health education, and the identification of health problems/risk factors and intervention. Conclusion: As quilombola mothers see children's consultations in a way similar to that recommended by the Ministry of Health and the scientific evidence shows their relevance to reduce morbidity and mortality rates, this research may guide educational measures aiming at the adherence of more children to the service.

Keywords: Growth and Development; Childcare; Ethnicity and Health; Interpersonal Relations; Social Vulnerability.

\section{Resumo}

Objetivo: Conhecer os significados da consulta de acompanhamento do crescimento e desenvolvimento na perspectiva de mães quilombolas. Método: Pesquisa qualitativa, realizadas com 26 mães de crianças menores de um ano que frequentavam a Unidade de Saúde da Família de llha de Maré, Bahia, Brasil. Os dados das entrevistas foram sistematizados através da análise de conteúdo temática e fundamentado no Interacionismo Simbólico. Resultados: Foram desveladas quatro categorias, que refletem o simbolismo de mães quilombolas acerca da consulta infantil: avaliação do crescimento; exame das condições gerais; orientação de educação à saúde; identificação de problemas/agravos e intervenção. Conclusão: Considerando que mães quilombolas significam as consultas infantis de modo semelhante ao preconizado pelo Ministério da Saúde e as evidências cientificas acerca da relevância destas para redução nos índices de morbimortalidade, a pesquisa poderá nortear processos educativos com fins na aderência de mais crianças ao serviço.

Palavras-chave: Crescimento e desenvolvimento; Cuidado da criança; Raça e saúde; Interação social; Vulnerabilidade social.

\section{Resumen}

Objetivo: Conocer los significados de la consulta de acompañamiento del crecimiento y desarrollo en la perspectiva de madres quilombolas. Método: Investigación cualitativa. Participaron 26 madres de niños menores de un año que frecuentaban la Unidad Salud de la Familia de llha de Maré, Bahia, Brasil. Los datos de las entrevistas fueron sistematizados a través del análisis de contenido temático y fundamentados en el Interaccionismo Simbólico. Resultados: Emergieron cuatro categorías que reflejan el simbolismo de madres quilombolas acerca de la consulta infantil: evaluación del crecimiento; examen de las condiciones generales; orientación de la educación a la salud; identificación de problemas/agravios e intervención. Conclusión: Considerando que las madres quilombolas significan las consultas infantiles de modo semejante al preconizado por el Ministerio de la Salud y las evidencias científicas acerca de la relevancia de éstas para reducción en los índices de morbimortalidad, la investigación podrá orientar procesos educativos para adherencia de más niños.

Palabras clave: Crecimiento y Desarrollo; Cuidado del Niño; Origen Étnico y Salud; Interacción Social; Vulnerabilidad Social. 


\section{INTRODUCTION}

The high rates of infant morbidity and mortality in quilombo communities demand strategic actions that offer measures to promote health, prevent diseases and provide treatments to this population. In this perspective, the adherence of children to growth and development monitoring (GDM) consultations may be a way to minimize these rates.

The first year of life presents a higher risk for children's health, contributing to the morbidity and mortality rates. ${ }^{1}$ In order to change this reality, the Brazilian Ministry of Health in 1984 implemented the Growth and Development Monitoring Program, which aims to improve the quality of life of children up to ten years of age. ${ }^{2}$ With the implementation of GDM consultations, which aim to recognize situations that endanger children's health and provide early interventions, there was a significant reduction in infant mortality between 2000 and 2010 , when the rate dropped by $47.6 \% .^{1,3}$

Despite the reduction of mortality rates over the years, Black children still have a greater risk of becoming ill or dying. In the United States, the probability of a child dying before the age of five is 1 in 140 live births, while in sub-Saharan Africa this probability increases to 1 in 12 births. ${ }^{4}$ In Brazil, in 2010, infant mortality among children of Black mothers was $40 \%$ higher than that of children of White mothers. ${ }^{1}$ Corroborating these data, a case-control study of 803 deaths in under one-year-old children indicates a positive and significant association between infant deaths and ethnicity. ${ }^{5}$ Thus, it is worth paying attention to the vulnerabilities experienced in quilombo communities.

Introduced in the Americas, the term 'quilombo' refers to a space occupied by a group of people, predominantly Black, but also Indians and whites in extreme poverty. In 2017, the Palmares Foundation registered 2465 quilombo communities in Brazil, with Bahia leading the ranking with 736 communities identified by the institution. ${ }^{6}$ On considering basic sanitation, housing, piped water, and access to public investment and services, it is worth noting that $74.7 \%$ of the quilombo communities in Brazil are in situations of social vulnerability. ${ }^{7}$ This is because poor living conditions lead to infectious diseases and the scarcity of services leads to delayed identification of genetic and chronic diseases, such as sickle cell anemia and hypertension. ${ }^{8}$

Knowledge of these aspects is extremely important in the sense of sensitizing health professionals of the need for special care for quilombola children, taking into account the customs, values and traditions of care in African cultures. This is ratified in the manuals of the Open University of the Brazilian National Health Service (SUS) ${ }^{9}$ that emphasize the importance of childcare, regardless of ethnicity, focused on individualities. To assist in this process, the State even provides complementary financial resources for Basic Care. ${ }^{10}$ Other countries have also been respecting popular knowledge in their established care models, as evidenced by research in Canada, England, South Africa, Kenya and Jordan; the use of traditional, complementary and alternative practices are highlighted as a right of the people and even fundamental in the care process and the adoption of health decisions. ${ }^{11,12}$ Thus, professionals need to promote health care that prioritizes peculiarities and respects the culture of the people during GDM consultations in the quilombo communities. ${ }^{9}$

Added to these issues is the unsatisfactory degree of adherence of children to GDM consultations with this problem being considered a challenge for health services. Among the reasons are the lack of understanding of the mothers about the need for these services ${ }^{3}$ and the maintenance of traditional practices carried out in communities such as quilombos. In these communities, the way of taking care of newborns includes giving them foods, including types of porridge, in the first days of life; breastfeeding the children of other mothers; the use of non-aseptic substances, including harmful substances, when caring for the umbilical stump care; the positioning of the infant at bedtime, exposing it to reflux and consequently risk of aspiration and self-medications, especially the administration of herbs and teas, regardless of the child's age.

Although the SUS already recognizes the value of traditional care, including instituting integrative practices, one study shows an adherence to erroneous or isolated behaviors that endanger children's health. ${ }^{13}$ In Nigeria, research also warns about the use of traditional practices that risk to human health. ${ }^{14}$ Hence, considering the importance of monitoring children in GDM consultations to prevent and treat diseases/risk factors and assuming that these sessions constitute a unique space for interactions between health professionals and the quilombo community, it is believed that the meaning attributed by quilombola mothers can guide actions to create links to the service and consequently reduce epidemiological indicators. Thus, this study aims to investigate the meanings of GDM consultations from the perspective of quilombola mothers.

\section{METHOD}

A descriptive research with a qualitative approach was performed in the light of symbolic interactionism, whose meaning is the central concept. This theoretical reference is based on the assumption that the meanings that a given group has about an object guides human social behavior, even though modifications can occur as people gain new knowledge. ${ }^{15}$ Thus, it can be considered a priori that the search for GDM consultations is anchored in the meaning attributed by the mothers of the children, who, in turn, are influenced by the customs and values embedded in the traditional knowledge of their own community. This traditional knowledge can be influenced by contact with people from the continent as well as interactions between quilombola mothers and health professionals, including those who follow the growth and development of their children, as this quilombo community is located less than $25 \mathrm{~km}$ from the state capital.

This study was developed in five quilombo communities located on Ilha de Maré in Bahia, Brazil: Praia Grande, Bananeira, Martelo, Ponta Grossa and Porto dos Cavalos. The 
choice for this study setting is justified by the fact that llha de Maré has one of the highest concentrations of Black people living in a municipality in Bahia, Brazil. Most of the population has access to drinking water and electricity however this coexists with lack of basic sanitation. As for health services, the island has a Family Health Unit (FHU), located in the community of Praia Grande.

The inclusion criteria for participation in the research were being a quilombola mother living on Ilha de Maré, having a child of less than one year old and having attended some GDM consultations. Considering that six children had never attended the FHU, 28 mothers were identified that met the criteria, two of whom did not agree about participating in the research. The 26 collaborating mothers signed informed consent forms following the criteria established in Resolution 466/2012 of the National Health Council. This research was approved by the Research Ethics Committee of the Nursing School of the Federal University of Bahia (\# 1.023.744 - CAAE 39922214.5.0000.5531).

A semi-structured interview technique, guided by a script prepared by the authors was used for data collection. The interviews were conducted between September 2014 and February 2015 at times previously scheduled with the women, in the facilities of the FHU or in the residences of the participant, always preserving the interviewee's privacy. The interviews were recorded with the permission of participants and later transcribed.

The data were systematized using the thematic content analysis method, following the phases of pre-analysis, material exploration, treatment, inference and interpretation of the results. Four categories emerged that express the meaning of quilombola mothers in having GDM consultations. The interpretation of the findings is based on the Theory of Symbolic Interactionism. ${ }^{15}$

\section{RESULTS}

Of the 26 mothers interviewed, 16 reported that they never stopped taking their children to the clinic and ten reported they had attended irregularly. The ages of the study participants ranged from 14 to 50 years with average age of 26 years. Most declared themselves Black or Mulatto, in stable relationships, with complete secondary education, working in the shellfish industry (collecting and selling shellfish) or as homemakers and with an average family income of one minimum wage.

The study identified the meanings of quilombola mothers about GDM consultations. These symbolizations, which encouraged them to go to the FHU, were grouped into the following categories:

\section{Growth assessment}

Quilombola mothers perceive the GDM consultation as a space that investigates whether their children's weight and height is adequate. Quilombola mothers take their children to the consultations because they believe that monitoring carried out by the health professional evaluates whether their children are healthy, as is observed in the following discourses:
I brought him to the clinic to see if he had grown [...]. I think it is important to see if he is well. (Addae)

It is important to do the follow up to check the growth of the child. (Winda)

The consultation is important for me to know how her health is, because they measure, weigh [...]. (Adanna)

\section{Examination of general health conditions}

Another meaning that influences the actions of mothers and their relationships with the health service is directly linked in the understanding of the value of the physical evaluation to know the state of health of their child. Thus, the behavior of quilombo mothers to attend GDM consultations is related to the understanding that professionals evaluate their child's health status. The professionals also inform them about aspects related to anatomy, physiology and nutritional status:

I take him for a consultation so that I can know how he is developing [...] because he (the doctor) examines the eyes, the eyelids, looks at him all over and tells me how to feed him. (Deka)

He (the doctor) examined her completely. [...] put her on her stomach and examined the intestine. He also put a device to listen to the heart. (Makini)

The consultation with the doctor is good. He measures the head, examines the body, measures everything, because he is very attentive. I want to see my daughter's development and I do not know how to examine her inside. (Zaila)

\section{Guidance on health education}

The understanding that in the GDM consultations they receive guidance aiming to promote the health of their children, as well as to prevent illnesses/risk factors, permeates the symbolism of quilombo mothers encouraging them to go to the FHU. Among the professional recommendations, the women mention information on food, hygiene and vaccinations, as the following discourses illustrate:

The nurse teaches things I did not know. She tells me what I should give her to eat, teaches me how to trim her nails, how to clean her. If the vaccinations are late, she tells me that I should bring them up to date. (Diara)

I find the consultation important to have proper guidance because the neighbors really like to recommend something (self-medication). So, for me not to get confused, it's good to have medical guidance. I listen carefully and patiently! (lori)

She (the nurse) advises on what is needed to improve the health of our children. (Zalika) 


\section{Identification of problems/risk factors and interventions}

Another symbolism shared by the interviewees refers to the consultation of GDM as an occasion to identify and diagnose health problems and risk factors of quilombola children for which guidance on therapy and drug treatments are needed. This meaning is also an incentive to go for a GDM consultation and attendance at the FHU.

I follow up every month, but when I see that he has fever, cough, diarrhea or is losing weight, I take him to see if he has pneumonia. (Deka)

If she has a fever, I take her for a consultation, because I need to know her weight, to give the right amount of drops of medicine. There was a time when she had lumps with pus on her head. (Urbi)

You need to come for a consultation when your child has a health problem for the professional to tell you the diagnosis. (Zarina)

\section{DISCUSSION}

The quilombo mothers state that the GDM consultation is a space that allows an evaluation of the weight and height of children. These growth-monitoring parameters, as recommended by the Ministry of Health, are also used to measure children in China. ${ }^{16}$ As quilombo mothers state, the meaning is related to the perception that this evaluation is an important predictor of the child's well-being. This is because by measuring the weight and height, the child's growth and nutritional status are monitored, allowing mothers to see if their children are healthy. ${ }^{17}$

It is important to reflect that the symbolism of the interface between the child's health and the adequacy of anthropometric measures (weight and height) may be related to social demands on the woman regarding child nutrition. We cannot disregard the social construction anchored in gender inequality, which attributes the responsibility for the feeding of children to women, whether through exclusive, partial or artificial breastfeeding..$^{18}$ In this perspective, information on weight gain, which is one of the main interests of the mother in the GDM consultation, may not necessarily mean full awareness of its importance, but rather the fear of feeling guilty if the child presents a problem that could even lead to death. In sub-Saharan Africa, malnutrition-related diseases are the main causes of child mortality, intensified by socioeconomic factors and accessibility to treatment and care. ${ }^{19}$

In order to meet nutritional needs and reduce their negative impacts on child morbidity and mortality, actions, such as the Family allowance (Bolsa Família) Program (FAP) given to needy families, have been created to combat poverty. This program is based on three central pillars: the transfer of income to alleviate poverty immediately, conditionalities, with a view to strengthening access to basic social rights in health, education and social assistance, and complementary programs that aim to create opportunities for families to overcome the situation of vulnerability and to break the intergenerational cycle of reproducing poverty. ${ }^{20}$

According to the Ministry of Social Development in December 2014, the FAP distributed a quantity in the order of 2.3 billion reals, reaching about 14 million families, including those who live in quilombos. It is worth mentioning that these have priority to receive the aid. In $2013,79.78 \%(n=64,000)$ of the 80,000 families in quilombos on the State Register for Social Programs (CadÚnico) were favored by the FAP. ${ }^{20}$ Research carried out with 11,282 beneficiaries confirms an improvement in the quality of food consumed in families enrolled in FAP, which reduces the low weight and height indexes associated with poor dietary conditions. ${ }^{21}$

Such interventions are important and necessary, especially considering the health situation in quilombos. In the context of 60 communities distributed in 22 of the 26 federative units of Brazil, a research developed to investigate the diagnoses of 2725 under five-year-old children consulted in health clinics, revealed that the growth deficit among quilombolas was, in proportional terms, $74.2 \%$ higher than the indicator recorded in the northeastern outback. The weight/age deficit presented a differential of $46.4 \% .{ }^{22}$ The description of quilombo children can even be noticed in a study carried out with 973 children aged between six and 59 months old living in 39 communities in the state of Alagoas, Brazil, who also had stature deficits and chronic malnutrition. Cases of severe anemia were reported in these children. ${ }^{21}$ Remembering that meanings are built on social and personal experiences laden with value and affection, ${ }^{15}$ it can be inferred that this scenario of greater vulnerability to illness may be inciting the construction of new symbologies by quilombo mothers, thus guiding their behaviors toward the services of the GDM.

In addition to the evaluation of growth, quilombo mothers also attribute meaning to the physical examination of the child by a professional. It is important to mention that, when performed in a judicious way, the physical examination distinguishes signs of normality from changes and the mother becomes satisfied when she perceives that the examination is performed attentively. ${ }^{24}$ As consultations are a space of sharing and exchanging symbolic-affective contents, they can constitute settings for the development harmonious relationships between the professional and the mother, enabling the process of counseling in respect to health and creating a link with the service.

This interaction with the mother, by opening spaces for the creation of a relationship of trust, also favors maternal empowerment to care for the child. Based on the impressions about the general health conditions of the child, the professional focuses on care to promote a healthy childhood. By guiding, the nurse allows greater participation of mothers and other family members in the care of the child, making them co-responsible for its health and, thus, the possibility of a stronger interaction. ${ }^{25}$ The new values that arise in the space of the consultations where the mothers are inserted help to construct meanings directed to the valorization of health education. 
A national study carried out with family members about their perception about childcare consultations in the Family Health Strategy program (FHS) concluded that during the consultations, it is essential to consider the sharing of knowledge through counseling. This approach increases the autonomy of the parents, ${ }^{26}$ reinforcing their position as a social subject capable of providing the best care for their child. Thus, it is inferred that explanations about childcare add to the self-confidence of the mother to look after her child, and thus reinforce interactions established between the mother and the health professional in the space of GDM consultations.

As interactions between health professionals and users make them more receptive to the advice and referrals, quilombo mothers mention that they receive guidance on food, hygiene and immunization, and consider these aspects essential to promote the health and prevent diseases of their children. A study carried out in Mexico with 25 mothers attending GDM consultations supports the importance of health education actions as the interviewees praise the professional approach to healthy eating and the prevention of accidents, while at the same time wanting guidance on sleep and rest, stimulation of child development and the prevention of domestic violence. ${ }^{27}$ It is considered that the educative process of counseling for the prevention of diseases, also symbolized by quilombo mothers as a sense of GDM consultations, substantially reduces the occurrence of diseases in their children. ${ }^{28,29}$

Another meaning revealed in the study refers to the attendance of consultations due to health problems. It should be noted that the mothers recognize that such evaluations are based on the professional's view that will inform them about the health of their child as the professional has clinical experience. Health professionals are often assigned the function of identifying disease early, and providing relevant interventions and timely referrals of children with growth and development problems. ${ }^{25}$ It is worth mentioning that the GDM consultation also constitutes a space for spontaneous demand, where children are received in order to solve emergency problems, albeit of low complexity, or to refer them to specialized services. ${ }^{30}$ Research, also carried out with quilombo mothers, supports spontaneous demand for attention in cases of complications, especially in vulnerable communities, where access to health care may be difficult due to the geographical location, lack of services and limitations in the professional context. ${ }^{31}$

Consultations as a space for interventions, mainly related to therapeutic interventions and drug therapy, was also identified by the interviewees. International studies carried out in Asia and South America ${ }^{32}$ converge on the trend towards attending health services in an attempt to treat diseases, especially focusing on the prescription of medicines. This warns us that, the mothers' desire for medications is observed even in the primary care setting, a situation that may be linked to the overvaluation of the medical care model. Interactions with professionals can explain the fact that the mothers take control of the values and contents valued in their particular universe, being modified and modifying their perceptions, so that they begin to rework symbols in the perspective of institutionalized healthcare.

It is interesting that the identification of meanings of GDM consultations for quilombo mothers are similar to the primary objectives advocated by the Ministry of Health, namely: to accompany physical growth, and the neuropsychomotor and intellectual development, to promote health and prevent common childhood illnesses, to check vaccinations, and to identify diseases and warning signs for appropriate treatment or referral. This monitoring carried out in the FHS by nurses and doctors, who evaluate and supervise the health status of children in an expanded context of what it is to be healthy, also enables the establishment of a bond and respect for maternal autonomy with a focus on improving the quality of childcare.

In this way, the care provided to the quilombo children reflects the care based on the guidelines advocated by the Ministry of Health, and is not necessarily focused on the specific characteristics of the quilombo population. However, it is important to note that the relevance of government programs and policies includes traditional practices in order to value the way of life of different populations such as those of the quilombos. Studies in several countries have already reported on the importance of incorporating such practices into institutional settings, as the need for this type of care is the right of health service users. ${ }^{11,12}$ They also point out that such practices should guide state obligations regarding these populations. ${ }^{11}$

Research shows that even though healthcare models take into account the peculiarities of the population, there is a tendency for their underutilization to the detriment of the reproduction of the curatorial medical-hegemonic model. ${ }^{33}$ This model, which has often been implemented in health clinics, prioritizes rapid care based on the complaint and the need for treatment when there are symptoms of diseases. This reality, however, is opposed to what the FHS advocates, which is an expansion of basic healthcare towards the incorporation of preventive, educational and curative practices that are closer to the daily life of the population, and especially of the more vulnerable groups with peculiar characteristics, such as quilombo communities. ${ }^{10}$

This behavior of mothers in the search for medication interventions, contrasting with the traditional practices of caring that are common in quilombo communities, is understandable when interpreted from the interactionist referential. As GDM consultations constitute an unparalleled space for interaction between health professionals and the quilombo community, it is believed that this sharing favors the acquisition of new knowledge that permits re-signifying phenomena. ${ }^{23}$ This meaning, as named in the theoretical perspective of symbolic interactionism, is an important element to understand human behavior, suitable to analyze processes of socialization and resocialization and also to study changes of opinions, behaviors, expectations and social requirements. ${ }^{15}$ 


\section{FINAL CONSIDERATIONS}

This study identified the collective meaning of quilombo mothers about GDM consultations, linking them to the idea of assessing growth, evaluating the general health conditions, guidance on health education and identifying problems/ risk factors and interventions. Although the people of these communities share values and customs based on African culture, the symbolism revealed does not differ from the actions planned for GDM care in the manuals of the Ministry of Health.

In the community studied, this symbolism is possibly the result of the interactions between mothers and health professionals, who participate in child healthcare programs that reproduces the thoughts and the actions traditionally incorporated by the hegemonic model of care. Thus, the experience of quilombola mothers with the professional care they received seems to exert an influence on their symbolism about childcare, guiding the maternal behavior in attending GDM consultations for their children.

The understanding of this social logic of transforming symbols about an object favors the design of educational actions to encourage other mothers to go to GDM consultations. However, we must be attentive to allow the quilombo community to move between identity processes and subjectivation of their origins and the new possibilities of healthcare.

As quilombo mothers see GDM consultations similar to what is recommended by the Ministry of Health and the scientific evidence shows their relevance to reduce morbidity and mortality rates in this population, it is believed that this research supports the design of health education measures aimed at the adherence of children to health programs.

Thus, although this study is limited by the fact that it is not possible to confirm whether health professionals consider the identity processes peculiar to the quilombo people in the child healthcare process, it contributes by favoring the health status of quilombo children.

\section{REFERENCES}

1. Instituto Brasileiro de Geografia e Estatística (BR). Censo Demográfico. Características da População e dos Domicílios. Resultados do Universo. Rio de Janeiro: IBGE; 2011. [cited 2017 Dec 22]. Available from: https://biblioteca.ibge.gov.br/visualizacao/periodicos/93/ cd_2010_caracteristicas_populacao_domicilios.pdf

2. Oliveira FFS, Oliveira ASS, Lima LHO, Marques MB, Felipe GF, Sena IVO. Child care consultations held by nurses within the family health strategy. Rev Rene [Internet]. 2013; [cited 2017 Sep 17]; 14(4):694-703. Available from: http://www.revistarene.ufc.br/revista/index.php/revista/ article/view/183/pdf_1

3. Gava C, Cardoso AM, Basta PC. Infant mortality by color or race from Rondonia, Brazilian Amazon. Rev Saúde Pública [Internet]. 2017; [cited 2017 Sep 17]; 51(35):1-9. Available from: https:// www.ncbi.nlm.nih.gov/pmc/articles/PMC5396493/pdf/0034-8910rsp-S1518-87872017051006411.pdf

4. Denno DM, Paul SL. Child Health and Survival in a Changing World. Pediatr Clin North Am [Internet]. 2017 Aug; [cited 2017 Sep 17]; 64(4):735-54. Available from: https://www.ncbi.nlm.nih.gov/ pubmed/28734507
5. Leal MC, Bittencourt SDA, Torres RMC, Niquini RP, Souza PRB Jr. Determinants of infant mortality in the Jequitinhonha Valley and in the North and Northeast regions of Brazil. Rev Saúde Pública. [Internet]. 2017; [cited 2017 Sep 17]; 51(12):1-9. Available from: http://www.scielo. br/pdf/rsp/v51/0034-8910-rsp-S1518-87872017051006391.pdf

6. Fundação Cultural Palmares (BR). Fundação Palmares certifica 29 comunidades quilombolas. Portal Brasil: Fundação Cultural Palmares; 2017. [cited 2017 Dec 22]. Available from: http://www.brasil.gov. br/cidadania-e-justica/2017/01/fundacao-palmares-certifica-29comunidades-quilombolas

7. Programa Brasil Quilombola (BR). Secretaria de Políticas de Promoção da Igualdade Racial. Guia de Políticas Públicas para Comunidades Quilombolas. Secretaria de Políticas de Promoção da Igualdade Racial; 2013. [cited 2017 Sep 15]. Available from: http://www.seppir.gov.br/ portal-antigo/arquivos-pdf/guia-de-acesso-a-politicas-publicas-do-pbq

8. Santos RC, Silva MS. Condições de vida e itinerários terapêuticos de quilombolas de Goiás. Saúde Soc [Internet]. 2014; [cited 2017 Sep 15]; 23(3):1049-63. Available from: http://www.scielo.br/pdf/sausoc/ v23n3/0104-1290-sausoc-23-3-1049.pdf

9. Ministério da Saúde (BR). Universidade Aberta do SUS. Curso Saúde da População Negra - Módulo 2. Plataforma Arouca: UNA-SUS [Internet];2015 [cited 2017 Dec 26]. Available from: https://www.unasus. gov.br/populacaonegra

10. Ministério da Saúde (BR). Secretaria de Atenção à Saúde. Departamento de Atenção Básica. Política Nacional de Atenção Básica. Brasília (DF): Ministério da Saúde; 2012. [cited 2017 Aug 3]. Available from: http://189.28.128.100/dab/docs/publicacoes/geral/pnab.pdf

11. Stuttaford M, Al Makhamreh S, Coomans F, Harrington J, Himonga C, Hundt GL. The right to traditional, complementary, and alternative health care. Glob Health Action [Internet]. 2014 Apr; [cited 2017 Sep 19]; 7:24121. DOI: 10.3402/gha.v7.24121. Available from: https://www. ncbi.nlm.nih.gov/pubmed/24767601

12. Auger M, Howell T, Gomes T. Moving toward holistic wellness, empowerment and self-determination for Indigenous peoples in Canada: Can traditional Indigenous health care practices increase ownership over health and health care decisions? J Public Health [Internet].2016 Dec; [cited 2017 Sep 19]; 27;107(4-5):e393-8. DOI: 10.17269/cjph.107.5366. Available from: https://www.ncbi.nlm.nih.gov/pubmed/28026704

13. Martins RC, Filgueiras TS, Albuquerque UP. Ethnobotany of Mautitia flexuosa (Arecaceae) in a Maroon community in central Brazil. Econ Bot [Internet]. 2012; [cited 2017 Aug 3]; 66:91-8. Available from: https:// odonto.ufg.br/up/133/o/ARTIGO_BURITI_ECON_BOTAN2012.pdf

14. Lawal FB, Taiwo JO, Oke GA. Factors influencing awareness and attendance of traditional oral health care practices by residents of a periurban community in Ibadan, Nigeria. Afr Health Sci [Internet]. 2015 Mar [cited 2017 Sep 19]; 15(1):233-9. DOI: 10.4314/ahs.v15i1.30. Available from: https://www.ncbi.nlm.nih.gov/pmc/articles/PMC4370159/

15. Carvalho VD, Borges LO, Rêgo DP. Interacionismo simbólico: origens, pressupostos e contribuições aos estudos em Psicologia Social. Psicol Ciênc Profissão [Internet]. 2010; [cited 2017 Aug 3]; 30(1):146-61. Available from: http://www.scielo.br/pdf/pcp/v30n1/v30n1a11.pdf

16. Prenkert M, Ehnfors M. Growth data of underprivileged children living in rural areas of Chin State, Burma/Myanmar, compared to the WHO reference growth standards: an observational study. BMJ Open [Internet]. 2016; [cited 2017 Aug 3]; 6(1):e009119. Available from: http://bmjopen.bmj.com/content/bmjopen/6/1/e009119.full.pdf. DOI: 10.1136/BMJOPEN-2015-009119

17. Salam RA, Das JK, Bhutta ZA. Current Issues and Priorities in Childhood nutrition, growth, and infections. J Nutr [Internet]. 2015 May [cited 2017 Aug 3]; 145(5):1116S-22S. Available from: https://www.ncbi. nlm.nih.gov/pubmed/?term=Current+Issues+and+Priorities+in+Child hood+nutrition $\% 2 \mathrm{C}+$ growth $\% 2 \mathrm{C}+$ and+infections

18. ljumba P, Doherty T, Jackson D, Tomlinson M, Sanders D, Swanevelder S et al. Effect of an integrated community-based package for maternal and newborn care on feeding patterns during the first 12 weeks of life: a clusterrandomized trial in a South African township. Public Health Nutr [Internet] 2015 Oct; [cited 2017 Aug 3]; 18(14):2660-8. Available from: https://www. ncbi.nlm.nih.gov/pmc/articles/PMC4564360/pdf/nihms-716297.pdf 
19. Tlou B, Sartorius B, Tanser F. Spatial-temporal dynamics and structural determinants of child and maternal mortality in a rural, high HIV burdened South African population, 2000-2014: a study. BMJ Open [Internet]. 2016 Jul; [cited 2017 Aug 3]; 6(7):e010013. Available from: https://www.ncbi. $\mathrm{nlm}$.nih.gov/pubmed/?term=Spatial-temporal+dynamics+and+structur al+determinants+of+child+and+maternal+mortality+in+a+rural\%2C+h igh+HIV+burdened+South+African+population $\% 2 \mathrm{C}+2000 \%$ E2\% $80 \%$ $932014 \% 3 A+a+$ study+protocol

20. Senna MCM, Brandão AA, Dalt SD. Family Allowance Program and the follow-up of the conditions related to the health field. Serv Soc Soc [Internet]. $2016 \mathrm{Jan} / \mathrm{Apr}$; [cited 2017 Aug 3]; 125:148-66. Available from: http://www.scielo.br/pdf/sssoc/n125/0101-6628-sssoc-125-0148.pdf

21. Martins AP, Monteiro CA. Impact of the Bolsa Família program on food availability of low-income Brazilian families: a quasi experimental study. BMC Public Health [Internet]. 2016 Aug 19; [cited 2017 Aug 3]; 16(1):827. Available from: https://www.ncbi.nlm.nih.gov/pubmed/?term=Impact+of +the+Bolsa+Fam\%C3\%ADlia+program+on+food+availability+of+low-in come+Brazilian+families\%3A+a+quasi+experimental+study

22. Paixão M, Rossetto I, Montovanele F, Carvano LM, orgs. Relatório anual das desigualdades raciais no Brasil; 2009-2010: Constituição Cidadã, seguridade social e seus efeitos sobre as assimetrias de cor ou raça [Internet]. Rio de Janeiro: Garamond; 2011; [cited 2017 Aug 14]. Available from: https://www.geledes.org.br/wp-content/ uploads/2014/05/Relatório_2009-2010.pdf

23. Ferreira HS, Lamenha ML, Xavier Júnior AFS, Cavalcante JC, Santos AM. Nutrição e saúde das crianças das comunidades remanescentes dos quilombos no Estado de Alagoas, Brasil. Rev Panam Salud Publica [Internet]. 2011; [cited 2017 Aug 14]; 30(1):51-8. Available from: http:// www.scielosp.org/pdf/rpsp/v30n1/v30n1a08.pdf

24. Santana MDR, Bezerra IMP, Santos RR, Benicio AL. Care to the child less than one year old: nursing practice perspective about child care. J Nurs UFPE On Line [Internet]. 2016 Feb; [cited 2017 Aug 14]; 10(2):576-84. Available from: https://periodicos.ufpe.br/revistas/ revistaenfermagem/article/view/10992

25. Ribeiro SP, Oliveira DS, Fernandes SLSA, Felzemburgh RDM, Camargo CL. Nurses' everyday activities in a child care clinic. Rev Enferm UERJ [Internet]. 2014 Jan/Feb; [cited 2017 Aug 3]; 22(1):89-95. Available from: http://www.facenf.uerj.br/v22n1/v22n1a14.pdf

26. Malaquias TSM, Gaíva MAM, Higarashi IH. Perceptions of the family members of children regarding well-child check-ups in the family healthcare strategy. Rev Gaúcha Enferm [Internet]. 2015 Mar; [cited
2017 Sep 20]; 36(1):62-8. Available from: http://www.scielo.br/scielo. php?script=sci_arttext\&pid=S1983-14472015000100062\&lng=en http://dx.doi.org/10.1590/1983-1447.2015.01.46907

27. Flores-Peña Y, Ortiz-Félix RE, Cárdenas-Villarreal VM. Percepções maternas do Cuidado à Criança Sadia. Rev Latino Am Enferm [Internet] $2012 \mathrm{Mar} / \mathrm{Apr}$; [cited 2017 Aug 3]; 20(2):1-7. Available from: http://www. scielo.br/pdf/rlae/v20n2/pt_09.pdf

28. Oliveira FFS, Oliveira ASSO, Lima LHO, Marques MB, Felipe GF, Sena IVO. Child care consultations held by nurses within the family health strategy. Rev Rene [Internet]. 2013; 14(4):694-703. Available from: http:// www.redalyc.org/html/3240/324028459005/

29. Yousafzai AK, Rasheed MA, Rizvi A, Armstrong R, Bhutta ZA. Effect of integrated responsive stimulation and nutrition interventions in the Lady Health Worker programme in Pakistan on child development, growth, and health outcomes: a cluster-randomised factorial effectiveness trial. Lancet [Internet]. 2014 Oct; [cited 2017 Dec 22]; 384(9950):1282-93. Available from: https://www.ncbi.nlm.nih.gov/pubmed/?term=Effect+o $\mathrm{f}+$ integrated+responsive+stimulation+and+nutrition+interventions+in+ the+Lady+Health+Worker+programme+in+Pakistan+on+child+develo pment\%2C+growth\%2C+and+health+outcomes $\% 3 \mathrm{~A}+\mathrm{a}+$ cluster-rando mised+factorial+effectiveness+trial

30. Baratieri T, Soares LG, Botti ML, Campanini AC. Consulta de enfermagem em puericultura: um enfoque nos registros de atendimentos. Rev Enferm UFSM [Internet]. 2014 Jan/Mar; [cited 2017 Aug 3]; 4(1):206-16 Available from: https://periodicos.ufsm.br/reufsm/article/view/8553/pdf

31. Siqueira SMC, Jesus VS, Camargo CL. Itinerário terapêutico em situações de urgência e emergência pediátrica em uma comunidade quilombola. Ciênc Saúde Coletiva [Internet]. 2016; [cited 2017 Aug 3]; 21(1):179-89. Available from: http://www.scielo.br/scielo. php?script=sci_abstract\&pid=S1413-81232016000100179\&lng=pt\& nrm=iso

32. Rahman AHMM, Rafieian-kopaei M. An ethno-phramacological study of plants used for traditional medication in Tangail district, Bangladesh. Eletronic Physician [Internet]. 2017 Jul; [cited 2017 Aug 3]; 9(7):475965. Available from: https://www.ncbi.nlm.nih.gov/pmc/articles/ PMC5586990/pdf/epj-09-4759.pdf

33. Baeta S, Maria F. Cultura y modelo biomédico: reflexiones em el proceso de salud-enfermedad. Comunidad Salud [Internet]. 2015; [cited 2017 Aug 3]; 13(2):81-4. Available from: http://bases.bireme.br/cgi-bin/ wxislind.exe/iah/online/? IsisScript=iah/iah.xis\&src=google\&base=LIL ACS\&lang=p\&nextAction=Ink\&exprSearch $=783083$ \&indexSearch $=I D$

\section{Financial support}

Brazilian National Council of Science and Technology (CNPq - Research grant); Research Support Foundation of the State of Bahia (FAPESB - Research grant), and Coordination for the Improvement of Higher Education Personnel (CAPES: Doctorate grant). 